\title{
A TRANSCRIAÇÃO LITERÁRIA COMO UMA METODOLOGIA DO ENSINO DE
}

TEATRO.

\section{RESUMO}

Tendo como base os processos de criação dos espetáculos “Ou tudo ou nada” e "O gigante egoísta” discute-se os espaços de trabalho na Universidade e na Escola a fim de perceber o lugar potente da sala de ensaio como campo de (re)invenção artística e construção de saberes. Percebendo o processo enquanto território de troca e experiência a partir do encontro entre aluno-ator e professor-artista.

PALAVRAS-CHAVE: Pedagogia do teatro. Teatro Narrativo. Transcriação. Processo de criação. Experiência.

\section{ABSTRACT}

Based on the creation process of the shows, "Ou Tudo ou Nada" (All or Nothing) and "O Gigante Egoísta” (The Selfish Giant), the work spaces at the University and at the School are discussed in order to perceive the potent place of the rehearsal room as an artistic (re)invention and knowledge building field. Perceiving the process as territory of exchange and experience from the meeting between student-actor and teacher-artist.

KEY WORDS: Theater Pedagogy. Narrative Theater. Transcreation. Creation Process. Experience.

“Ou tudo ou nada” foi uma adaptação do conto O pescador e sua mulher dos irmãos Grimm teatralizado enquanto componente curricular do curso de Teatro - Licenciatura da Universidade Federal do Ceará. “O gigante egoísta” foi uma adaptação do conto homônimo de Oscar Wilde apresentado por alunos do ensino fundamental II do Colégio Nossa Senhora das Graças em Fortaleza - Ceará. Percebendo os espaços de trabalho - Universidade e Escola - discuto o processo pedagógico realizado para se chegar a transcriação cênica de um texto literário.

O fazer teatral escolar é visto, por alguns colegas acadêmicos, como lugar menor no ensino de artes na escola, pois é pensado como um evento tornando-se um produto. Mas do contrário, quando uma turma de alguma disciplina do ensino superior apresenta um trabalho final, um produto cênico, aquilo é tido como obra artística. Não quero aqui levantar os questionamentos do que é arte, mas quero pensar o que invalidaria a prática escolar e o que valida a prática de estudantes de graduação. 
Ao pensarmos em um produto cênico, o resultado, estamos esquecendo todo o processo anterior que possibilitou seu acontecimento. Sei que lidamos com níveis distintos de discussões no ensino superior e na educação básica e que os processos didáticos-pedagógicos por vezes são distintos, mas enquanto prática artística não se diferem e têm como objetivo em comum a realização cênica. Considerando o processo de criação como território de saberexperiência traço uma metodologia de criação de um processo artístico e aplico em ambos os espaços - Universidade e Escola, a fim de chegar em um espetáculo e colher os resultados dos dois processos que são distintos.

Nesse processo de transcriação os procedimentos foram os mesmos em ambos os espaços. Na seguinte ordem: contato com o material (texto literário), discussões sobre temáticas encontradas no texto, livre improvisação, construção de texto dramático, estudo do texto dramático, ensaios e apresentações. No trajeto de construção do invento cênico mostrou-se uma potência imaginativa na tentativa de aproximação entre linguagem literária e teatral. Como Sinisterra (2016) fala que há textos que carregam consigo uma teatralidade textual que dispara a inventividade nos sujeitos atuantes.

Essa escolha por textos não dramáticos como elemento motriz da criação, possibilita uma (re)invenção do procedimento artístico. A criação torna-se uma rede em que, depois de iniciada, não se pode mais distinguir o ponto de partida, uma vez que o processo se alimenta dele mesmo e nesse movimento de idas e vindas (re)processa-se e (re)transforma-se possibilitando aos envolvidos uma propriedade maior sobre o fazer.

Na busca pelo invento cênico cada sujeito acaba por (re)inventar a si mesmo e (re)descobre novas possibilidades imagéticas, corpóreas e imaginativas, libertando sua expressividade. A pesquisa de voz, corpo e imagem acaba por alargar os limites até então estabelecidos por cada um a suas próprias possibilidades criativas, sobretudo o professor-artista que encontra em sua prática novos elementos didáticos agregando saberes.

Podemos perceber a importância do processo de criação ao presenciarmos a realização cênica. Em ambos os casos percebemos atores vivos, presentes, dominando o palco e as situações de cena, sempre alertas e em situação de jogo. Os alunos-atores, tanto na Universidade como na Escola, ao passarem pelo processo de transcriação de um texto literário, percebem algumas instâncias da artesania teatral como o trabalho de autor, ator e diretor. E tendo esses domínios dos processos tornam-se sujeitos conscientes de seu papel.

\section{REFERENCIAS BIBLIOGRÁFICAS}


DESGRANGES, Flávio. A pedagogia do teatro: provocações e dialogismo / Flávio Desgranges. - 3. ed. - São Paulo : Editora Hucitec : Edições Mandacaru, 2011.

SINISTERRA, José Sanchis, 1940- Da literatura ao palco: dramaturgia de textos narrativos / José Sanchis Sinisterra; Tradução Antonio Fernando Borges. - 1. Ed. - São Paulo: É Realizações, 2016. 